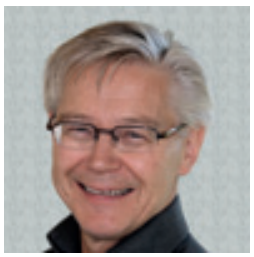

\title{
Maten, blodet, helsa
}

\section{Om tilhøvet mellom mat og blod.}

Nei, det skal ikkje handla om blodmat, endå det kunne eg godt ha skrive om, bondegut som eg er og oppvaksen på ein gard, i ei tid der det enno var lov å slakta og vidarebehandla kjøt og blod. Mattilsynet var ikkje oppfunne i dei første tiåra etter krigen, verken som fenomen eller ord.

Det som er ærendet mitt, er tilhøvet mellom mat og blod. Maten er energien, drivstoffet. Blodet er fordelaren og formidlaren av drivstoffet rundt til cellene i kroppen. Då er det, reint logisk, to grunnleggjande spørsmål som burde melda seg temmeleg omgåande: For det første - er det nett det same kva slags type energi me puttar i oss, berre me får i oss energi? For det andre - betyr det ingen ting kva slags type blod me har, når det gjeld vår evne til å nyttiggjera oss denne energien og få han ut i kroppen?

Oppsiktvekkjande er det at eg som fornuftig vesen ikkje stilte desse to spørsmåla før eg var godt over 50 år. (Endå rett skal vera rett; det var møtet med ein homøopat og fysioterapeut i Lindesnes eg kan takka for dette!) Då desse to spørsmåla vel hadde sige inn i meg, tykte eg det var endå meir oppsiktvekkjande at legar og helsevesen slik eg har lært dei å kjenna - ikkje har gjort meir ut av dette.

Alle veit jo at til og med ei så primitiv innretning som bilmotoren streikar berre han får i seg bensin med feil oktan. Og så skulle ikkje funksjonen til denne usannsynleg finstilte og kompliserte motoren som kroppen vår er, vera svært ømfintleg for kva me puttar på tanken?
Besøket mitt hos homøopaten i Lindesnes endra livet mitt. Han visste eg var i god fysisk form; det var ikkje det. Men - «viss du ikkje justerer det du drikk og et, kjem du til å gå rett i veggen», sa han. Hans klare råd var: Kutt ut kaffe, te, mjølk og reduser bl.a. inntaket av sukker og mjølprodukt. Berre etter to-tre månader med det nye inntaksregimet var tilstanden i kroppen annleis. Ingen får innbilla meg at endringa i velvære ikkje kom frå justering av kosthaldet. «Evidensbasert» er (med rette) det nye mantraet $\mathrm{i}$ både legevitskap og andre vitskapar. Mine røynsler med min kropp er evidensbasert så det held.

Ikkje overraskande vart interessa mi òg vekt for samanhengen mellom blodtype og mat. Ikkje visste eg kva blodtype eg hadde, og ikkje visste eg at berre ein av dei blodtypane menneska har på jorda i dag, har funnest svært lenge. Om eg ikkje har mistydd, hadde alle menneske blodtype $\mathrm{O}$ så seint som for ti tusen år sidan. $\mathrm{O}$ er «steinalderblodet», det me alltid har hatt i oss. Type A og B er unge, berre nokre få tusen år. $\mathrm{Og} \mathrm{AB}$ er visst nok yngre enn Det nye testamente! Er det då overtruisk å meina at alle me som har $\mathrm{O}$, ville ha nytte av å skjela til fangstlivet $i$ den hundretusenårige steinalderen, medan dei som har det ganske nye A, nok er betre tilpassa jordbruksalderens kornprodukt? Formasteleg sagt: Når eg meiner å ha hatt helseutbyte av å redusera kraftig inntaket av t.d. kveitemjøl, kan det kanskje ha ein samanheng med at eg har O, steinalderblodet?

Litt malurt i begeret til slutt. Det viser seg at mykje av den såkalla sunne maten ikkje er sunn likevel. To tredelar av dei varene som matvareindustrien marknads- fører som å ha «helsefremjande» effekt (for kroppen, minnet, helsa), syner seg ikkje å ha det likevel. Det rapporterte nyleg EFSA, det europeiske organet for matvaresikkerheit.

Men det fortel oss berre det me burde vita: Ein skal vera skeptisk til alle som tener pengar på vår naturgjevne lyst til å leva lenge og vel. Bortsett frå at kvar og ein ? ut frå mine røynsler? burde finna fram til ein føremålstenleg «matprofil» for seg sjølv, så er det den gamaldagse, langsame maten utan mykje tilsetningar me alle bør satsa på. Kort veg frå produsent til konsument, kort veg frå råvare til rett. Tradisjonell mat kunne òg vera like haldbar som moderne industrimat. Sild frå Sunnmøre, røykt i fleire omgangar, var såleis mat om bord på slaveskipa frå Afrika til Amerika. Ho tålte både fukt og temperatursvingingar over lengre tid.

Det holistiske synet, å sjå heile mennesket under eitt, har med god grunn fått innpass i helsevesenet vårt. «Holistisk» heng saman med eit gresk ord for «heilskap». Kropp og sjel, mat og velvære heng i hop. Det er då det er hyggeleg å vera filolog og koma med forklaringa på ordet «helse». «Helse» kjem frå «heilse» for meir enn tusen år sidan og er danna ut frå adjektivet «heil». Har du helsa, er du heil - du har ikkje manglar.

Med andre ord: Det er lite nytt under sola.

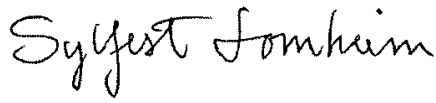

\section{I neste nummer:}

Medisinens kirurgisering

Motesykdommer på 1800-tallet

Må penicillin tas utenom

måltider?
Exit tuberkulosetester?

Levertransplantasjon

Legelisens for eldre 